\title{
THE JUDGMENT OF THE EUROPEAN COURT OF JUSTICE OF 22 SEPTEMBER 2020 C-724/18 AND ITS IMPACT ON THE REAL ESTATE MARKET IN THE EU
}

Assist. Prof. Ewelina Badura, Ph. D.*

\author{
UDK: 347.453(4)EU \\ 339.923:061.1>(4)EU \\ 341.645(4)EU:347.453 \\ DOI: 10.3935/zpfz.71.1.04 \\ Prethodno znanstveno priopćenje \\ Primljeno: ožujak 2021.
}

In 2020 two significant events affected the property market. The first one was the pandemic of COVID-19, which brought unprecedented uncertainty and resulted in a dramatic drop in property prices on rental market and hampered growth of the sales market. Another significant event this article is going to examine was the judgment C-724/18 of the European Court of Justice issued on 22 September 2020. The ECJ ruled that the authorisation scheme for short-term rental does not constitute a breach of the freedom of services warranted by the EU. The judgment concerns the legitimacy of the constraints imposed by local authorities on entrepreneurs operating short-term rentals. It also establishes the applicability of the EU's Services Directive $(2006 / 123 / E C)^{1}$ to short-term rental. The ECJ holds in the judgment that the measure requiring an authorisation for short-term rental aimed at tackling shortage of long-term rental housing represents an overriding reason of public interest and as such it is justified. The article analyses the importance of the ECJ judgment for the market of short-term rentals, in view of the existing legal regulations and in respect of its possible consequences for short-term rental in the EU member states.

Keywords: rental; property; pandemic; CJEU; tourist

Ewelina Badura, Ph. D., Assistant Professor, Institute of Law, Cracow University of Economics, Rakowicka 27, 31-510 Kraków, Poland; badurae@uek.krakow.pl;

ORCID ID: orcid.org/0000-0002-5514-6299

1 Directive 2006/123/EC of the European Parliament and of the Council of 12 December 2006 on services in the internal market, OJ L 376, 27.12.2006, pp. 36-68. 


\section{INTRODUCTION}

Short-term rental has been a very popular form of accommodation for many years now. ${ }^{2}$ Booking platforms, such as Airbnb make it possible to find accommodation not only in hotels but also in private apartments in attractive locations. ${ }^{3}$ In order to come up with an appropriate policy regulating short-term rental every legislation should be able to adopt legal regulations that address its specific social and economic needs. ${ }^{4}$ On 22 September in the judgment C-724/18 the ECJ determined that the Member States have the right to impose restrictions on short-term rental taking into account certain criteria. Under the judgment the requirement to obtain an authorisation for a repetitive short-term rental of accommodation to tourists does not breach the EU law. As the development of new technologies and the growing popularity of booking platforms as well as of the idea of sharing economy ${ }^{5}$ all contribute to the expansion of the market of short-term rentals, eventually every city will have to face up the challenges it poses. In light of various issues accompanying short-term rental, coupled with the fact that many states lack appropriate regulations in this area, it seems necessary to take a closer look at short-term rental and seek appropriate solutions. The ECJ judgment provides a great starting point for discussion. It

2 The issue of accommodation services in the context of legal issues was the subject of various studies. For example, the issues of rapid technology development were presented in the context of unsuccessful changes in legal regulations (Varma, A.; Jukic, N.; Pestek, A.; Shultz, C.J.; Nestorov, S., Airbnb: exciting innovation or passing fad?, Tourism Management Perspectives, vol. 20, 2016, pp. 228-237). Attempts have been made to introduce legal regulations restricting accommodation services in US cities (McNamara, B., Airbnb: a not so safe resting place, Colorado Technology Law Journal, vol. 13, 2015, pp. 149-170; Miller, S.; Jefferson-Jones, J., Airbnb and the battle between Internet exceptionalism and local control of land use, Probate and Property vol. 31, 2017, pp. 36-39).

3 Edelman, B. G.; Geradin, D., Efficiencies and regulatory shortcuts: How should we regulate companies like Airbnb and Uber?, The Stanford Technology Law Review, vol. 19, no. 2, 2016, pp. 293-328.

4 At the national and local level (city, county, region, district etc.), depending on the specificity and needs of a country.

5 Hamari, J.; Sjöklint, M.; Ukkonen, A., The Sharing Economy: Why People Participate in Collaborative Consumption, Journal of the Association for Information Science and Technology, vol. 67, no. 9, 2016, pp. 2047-2059. See also Aloni, E., Pluralism and regulatory response to the sharing economy, in: Davidson, N.; Michele, F.; Infranca, J. (ed.), Cambridge handbook of the law of the sharing economy, Cambridge University Press, Cambridge, 2018, p. 101-120. 
is therefore worth considering the opportunities provided by this judgment as well as its possible impact. ${ }^{6}$

\section{SHORT-TERM RENTAL IN THE SELECTED EU MEMBER STATES}

Online platforms providing booking services such as Booking or Airbnb have revolutionised short-term rental market. They have had a great impact on the way people travel and seek accomodation and in certain countries they have also led to legislative changes. Even though the institution of short-term rental is nothing new, it owes its popularity to booking platforms, which made this option available virtually all over the world. However, presently many cities have introduced numerous restrictions on short-term rental. The regulations are often local and they vary between the states and even cities within the same state. Certain solutions in selected cities in the EU are presented below.

German lands may adopt regulations ${ }^{7}$ prohibiting the use of appartments for non-residential purposes if it may lead to shortages of housing for long-term rent $^{8}$ (Article 6 section I (I l) MRVerbG). Such solutions may also be adopted in the case of existing shortages in a given area. Such solutions have been adopted in Berlin, which bans short-term rental of entire appartments via booking platforms. ${ }^{9}$ However, separate rooms can be rented on condition that the rented area represents less than 50\% of the size of the appartment. German law also imposes an obligation to obtain an authorisation for rental services and those who violate this regulation are subject to severe fines. ${ }^{10}$

6 Espinosa, T. P., The cost of sharing and the common law: How to address the negative externalities of home-sharing, Chapman Law Review, vol. 19, 2016, pp. 597.

7 Gesetz zur Verbesserung des Mietrechts und zur Begrenzung des Mietanstiegs sowie zur Regelung von Ingenieur- und Architektenleistungen (Law to improve tenancy law and to limit rent increases and regulate engineering and architectural services) (Mietrechtsverbesserungsgesetz - MRVerbG) of 4.11.1971, Rental Law Improvement Act.

8 For more see: Kaźmierczyk, A., Issues of short-term rental in light of EU and member states' regulations, PWPM - Review of International, European and Comparative Law, vol. XVII, 2020, pp. 192-193.

9 Ibid.

10 See $\$ 4$ I 7 ZwVbGO. 
French municipalities ${ }^{11}$ have the right to decide on the manner of registering short-term rentals. ${ }^{12}$ This entitlement pertains to the cities with the population over 200000 residents, including Paris. Apart from this, in France the procedure that governs short-term rental depends on the category the apartment falls into: primary residence, secondary residence (Fr. résidence sécondaire), or turist residence (Fr. meublés de touriste). ${ }^{13}$ Restriction in this area concerns the number of days in a year for which the apartment can be rented. The apartment that serves as the primary residence can be rented for the maximum number of 120 days in a year and a fine can be imposed on the owner for exceeding this limit. The owner must live in the property for the remaining part of the year. Apartments for short-term rental must also be registered..$^{14}$

Spanish regulations provide additional protections for tenants and give property owners greater powers to influence the rental of 'holiday' properties. ${ }^{15}$ Under Spanish law the three-fifths majority of building owners can decide to restrict or ban short-term rentals in their property (Article 17 (12) LAU). ${ }^{16}$ Online booking services are obliged to submit details of all their operations, including the data of the service users to Spanish tax authorities. ${ }^{17}$ Barcelona was the first city to regulate short-term rentals and under the law in force in Madrid apartments can be rented for a maximum of ninety days per year. ${ }^{18}$

11 The Law for a Digital Republic, Loi n 2016-1321 du 7.10.2016 no 1, available at: www.legifrance.gouv.fr.

12 Rules for short-term rental as well as penalties for non-compliance with short-term rental limits were introduced in 2018 by ELAN Act, ELAN. Loi n 2018-1021 du 23.11.2018 portant évolution du logement, de l'aménagement et du numérique (Loi ELAN), JORF nr 0272, 24.11.2018, nr 1 (The law on the evolution of housing, land management and digital technology - ELAN). This law also defines the new type of short-term rental "mobile rental", available at: www.legifrance.gouv.fr.

13 Kaźmierczyk, A., op. cit. (fn. 7), p. 189.

14 See Articles L631-7 - L631-9 of the Code de la construction et de l'habitation (Code of Construction and Housing), available at: www.legifrance.gouv.fr.

15 See Act: Ley de Arrendamientos Urbanos (LAU) Real Decreto-ley 7/2019, de 1 de marzo, de medidas urgentes en materia de vivienda y alquiler (Urban Leasing Law (LAU) Royal Decree-Law 7/2019, of March 1, on urgent measures regarding housing and rent), available at: https://www.boe.es/buscar/doc.php?id=BOE-A-2019-3108

16 Available at: https://www.conceptosjuridicos.com/lph-articulo-3/ and see also: Article 10 of Ley de Propiedad Horizontal (LPH) 21.07.1960, Ley 49/1960, available at: https://www.conceptosjuridicos.com/ley-de-propiedad-horizontal/.

17 According to Full disclosure agreements signed in 2018 between the Spanish Tax Office and property portals.

18 Badura, E., Legal aspects of short-term lease agreements - on a comparative background, Societas et Iurisprudentia, vol. VIII, 2020, pp. 61. 
The situation in Poland is quite different, as there is no legal definition of condo-hotel and apart-hotel, which have not even been taken into account in the statistics of the Polish Main Statistical Office. ${ }^{19}$ They are not regulated even in other provisions pertaining to hotel services. Absence of relevant legislation ${ }^{20}$ raises many questions, concerning safety, taxes, illegal hostels. ${ }^{21}$ Those who avail themselves of the services of short-term rental operators are awarded protection only on general terms under the Polish Civil Code. Currently Polish regulations do not specify even basic requirements related to short-term rentals, such as, to give just one example, what kind of property can be designated for such a purpose. ${ }^{22}$ Local authorities have no legal grounds to control the safety of such properties.

\section{THE CASE OF FRENCH SHORT-TERM RENTAL OPERATORS BEFORE THE ECJ}

The case of Cali Apartments and HX came before the European Court of Justice following a preliminary question from the French Court of Cassation. The subject-matter of the dispute before the national court concerned the obligation to obtain an authorisation for repetitive and short-term rental of apartments to tourists. As has been mentioned above, in the case of French municipalities with more than 200000 inhabitants $^{23}$ it is necessary to obtain a relevant authorisation if one wishes to change the use of a dwelling to short-term rental.

Both Cali Apartments and HX owned apartments in Paris. In 2015, Paris city services found that they were renting out their apartments to tourists through the online booking platform Airbnb without the required authorisation. The court in Paris fined Cali Apartments and HX and ordered that the

19 Ustawa z dnia 29 czerwca 1995 r. o statystyce publicznej (Dz.U. z 2020, poz. 443) (Act of June 29, 1995 on public statistics), available at: https://stat.gov.pl.

20 For example, while concerning property tax, the recognition of a short-term rental as an economic activity will lead to the taxation of short-term rentals at a higher rate - like for service premises. As regards income tax, it is subject to taxation as another source of income. Short-term rental has not been defined for income tax purposes. Paid access to the premises occurs as part of a private lease or as part of an economic activity. Basically, a distinction one from the other follows by scale of earnings.

${ }^{21}$ Gottlieb, C., Residential Short-Term Rentals: Should Local Governments Regulate the "Industry"?, Planning \& Environmental Law, 2013, pp. 34-61.

Strzelczyk, R., Prawo nieruchomości (Real Estate Law), C.H. Beck, 2019, pp. 415-423.

23 Article L. 631-7 Code de la construction et de l'habitation (Code of Construction and Housing). 
residential use of the properties be restored. Subsequently, the court of appeal upheld this judgment. It was also demonstrated that the premises in question had been rented repeatedly and without the prior authorization, in violation of the Building and Housing Code.

Cali Apartments and HX filed a cassation appeal with the cassation court, claiming that the judgments violated the principle of the priority of the EU law. ${ }^{24}$ The parties claimed in their appeal that the judgments failed to demonstrate that the restriction of freedom of services resulting from the national regulations is justified by overriding reasons relating to the public interest ${ }^{25}$ and that it has not been demonstrated that the objective pursued may not be achieved by less restrictive measures. Furthermore, the appellants held that the restriction in the form of the obligation to have a relevant authorization failed to meet the criteria from the requirements of the Services Directive.

The cassation court expressed doubts as to whether the short-term accommodation services fall within the scope of the Directive 2006/123/EC. According to the wording of the Directive, it applies to the facts of the main proceedings and, as regards rental of furnished tourist units, it is supplemented by the notification system set forth in the provisions of the Tourism Code, under which the operator of a short-term rental must notify the Mayor of the municipality where the apartment is located. Such a notification is not mandatory if the apartment is the primary residence of the landlord.

\section{PREJUDICIAL QUESTIONS}

The cassation court applied to the European Court of Justice for a prejudicial judgment in respect of the compliance of the national regulation with the Directive 2006/123/EC on the services in the internal market. Each of the applications of 21 and 22 November 2018 (cases C-724/18 ${ }^{26}$ and C-727/18

24 Biernat, S., Zasada pierwszeństwa prawa unijnego po Traktacie z Lizbony (The principle of the primacy of EU law after the Lisbon Treaty), Gdańskie Studia Prawnicze, vol. XXV, 2011, pp. 47-61.

25 See: Article 9, directive 2006/123/EC.

26 Judgment of the CJEU, Case C-724/18: Reference for a preliminary ruling from the Cour de cassation (France) on 21 November 2018 - Cali Apartments SCI / Procureur général près la cour d'appel de Paris, Ville de Paris, OJ C 35, 28.1.2019, pp. 12-13.

27 Case C-727/18: Reference for a preliminary ruling from the Cour de cassation (France) on 22 November 2018 - HX / Procureur général près la cour d'appel de Paris, Ville de Paris, OJ C 35, 28.1.2019, pp. 13-14. 
respectively) contained six prejudicial questions. ${ }^{28}$ French national court wished to determine whether the restrictions on short-term rental provided for by the national law were consistent with the Directive 2006/123/EC on services in the internal market.

Several months prior to the judgment of the Court of Justice the Advocate General Michal Bobek had issued an important opinion ${ }^{29}$ in the case of Cali and HX, focusing on the possibility of applying the Services Directive to short-term rental and on the viability of making such rental dependent on the possession of the administrative authorisation. The Advocate General also took into account the issue of the shortage of long-term rental housing as the overriding reason relating to the public interest that constitutes grounds for the requirement to obtain authorisation for short-term rental. The Advocate General concluded that the Services Directive is applicable to national and local provisions regulating short-term rental. ${ }^{30}$ Furthermore, the Advocate General also held that the Services Directive allows for national and municipal provisions that impose restrictions on short-term rental (such as the regulations in force in Paris), on condition that they are proportionate and non-discriminatory, which is for the referring court to verify. The Court of Justice reached the same conclusions in the judgment C-724/18.

\section{JUDGMENT OF THE EUROPEAN COURT OF JUSTICE OF 22 SEPTEMBER 2020 (C-724/18)}

In the key thesis of the judgment in the case of Cali Apartments SCI and HX against Procureur général près la cour d'appel de Paris i Ville de Paris (C-724/18 i C-727/18) the Grand Chamber of the Court of Justice ruled that national legislation providing for authorisation for short-term rental to tourists is consistent with the EU law. It has deemed that combating the shortage of long-term housing represents an overriding reason of public interest and therefore it provides grounds for implementation of legal restrictions on short-term rental.

28 See: point 26 of the Judgment.

29 Opinion of Advocate General Bobek of 2 April 2020 in the case C-724/18, Cali Apartments SCI i HX v. Procureur général près la cour d'appel de Paris i Ville de Paris, available at: http://curia.europa.eu/juris/celex.jsf?celex $=62018 \mathrm{CC} 0724 \&$ langl $=$ pl\&type $=\mathrm{TXT} \&$ ancre $=$.

30 See: point 44 and 63 Opinion of Advocate General Bobek in the case C-724/18, Cali Apartments SCI i HX v. Procureur général près la cour d'appel de Paris i Ville de Paris, available at: http://curia.europa.eu/juris/celex.jsf?celex $=62018 \mathrm{CC} 0724 \&$ langl $=$ pl\&type $=$ TXT\&ancre $=$, hereinafter referred to as the ombudsman's opinion. 
The Court of Justice examined the issue of authorisation that requires from the short-term rental operator to take certain steps and from the relevant authorities to issue a formal decision granting him the permission for operations. ${ }^{31}$ Another issue that was raised concerned the overriding reasons relating to the public interest ${ }^{32}$ on which Member States may rely. According to the ECJ case law they are: the protection of the urban environment ${ }^{33}$, the aims of social policy, and, last but not least, the shortage of housing for long-term rental.

ECJ held in the judgment that the service activity consisting in repeated, short-term renting out furnished residential units to tourists does not fall within the definition of "services" set forth in the Article 4 (l) of the Directive 2006/123/EC and it is not listed among the activities that are excluded from the application of the Directive under the provisions of the Article 3 (2). The judgment confirms that the provisions imposing the obligation to obtain an administrative decision of a competent authority granting a service provider a permission to operate fall within the scope of the definition of an authorisation scheme set forth in Article 4, paragraph 6 of the said Directive.

Paragraph 109 of the Judgment indicates that the Directive 2006/123/EC applies to the national regulations of a Member State that pertain to business operations consisting in repetitive, short-term rental of furnished accommodation to transient clientele who do not take up residence there. Furthermore, the Services Directive grants national authorities the power to establish, within the framework set out in that regulation, the conditions of authorisation in light of the objectives of social diversity, taking into account the characteristics of local housing markets and the need to tackle the problem of housing shortage.

\subsection{Compliance with the Services Directive 2006/123/EC}

Access to the market as provided by Article 9 of the Services Directive 2006/123/EC consists ${ }^{34}$ in the right of service providers to operate in the territory

31 See Judgment of the CJEU, Case C-360/15 and Case C-31/16, X and Visser, EU:C:2018:44, and also Judgment of the CJEU, Case C-393/17, Kirschstein, EU:C:2019:563.

32 See Judgment of the CJEU, Case C-567/07, Woningstichting Sint Servatius, EU:C:2009:593, and also Judgment of the CJEU, Case C-197/11 and C-203/11, EU:C:2013:288.

33 See point 135 Judgment of the CJEU, Case C-360/15 i C-31/16, X and Visser, EU:C:2018:44.

34 Hatzopoulos, V.; Roma, S., Caring for sharing? The collaborative economy under EU law, Common Market Law Review, vol. 57, no. 1, 2017, p. 100. 
of the Member State where they are established or in a different Member State. In the judgment C-724/18 the ECJ allows short-term rentals to be subject to authorization and, by the same token, it sets out the requirements that should be met for such authorisations to be considered compatible with EU law. According to Article 9 (l) (a) of Directive 2006/123/EC, authorisation schemes must not be discriminatory. Discrimination on grounds of nationality is not the only form of discrimination prohibited. The fact that the Directive applies exclusively to internal situations means that the non-discrimination criteria also extend to the grounds set out in Article 21 (1) of the Charter of Fundamental Rights. ${ }^{35}$

The judgment demonstrates that according to the ECJ the primary goal of the regulation in question is to establish means to prevent the shortage of long-term rental housing, limited access to housing and tensions on property market, which constitute the overriding reasons relating to the public interest. The ECJ also established that the French regulations are proportionate to the pursued objective as the constraints they impose are limited to rental activity while excluding premises which are the primary place of residence and the authorisation scheme they provide for has a narrow geographical scope. In addition, the objective pursued could not have been achieved by less restrictive measures.

\subsection{The criterium of proportionality and other criteria for authorisation}

The ECJ held that the need for authorisation requirement aimed at preventing deterioration of the access to housing and at protecting landlords and tenants constitutes an overriding reason relating to the public interest as stipulated in Article 9 (1) b of the Service Directive (paragraphs 65 to 68 in connection with paragraphs 96 to 104 of the Judgment). As has been rightly pointed out, the authorisation scheme is justified by overriding reason relating to the public interest and the purpose of the scheme cannot be achieved by less restrictive means (the so-called criterion of proportionality). According to the Judgment (paragraphs 69 and 73) French regulation is proportionate to the pursued objective and limited to rental activity, as it excludes the apartments that are the primary residence of the landlords and it provides for the authorisation

35 Szejna, A.; Kosicki, A., Karta Praw Podstawowych Unii Europejskiej i jej znaczenie dla Polski i Europy (The Charter of Fundamental Rights of the European Union and its significance for Poland and Europe), Fundacja Praw Podstawowych, Warszawa, 2008, p. 5. 
scheme with a limited geographical scope. Furthermore, the pursued objective could not have been achieved with less restrictive means.

Under Article 10 (1) of the Directive 2006/123/EC authorisation schemes are based on criteria that prevent competent authorities from exercising their powers in an arbitrary manner. Paragraph 2 of the above regulation provides that such criteria must be non-discriminatory, justified by overriding reason relating to the public interest and proportionate to the objective pursued. In the case in question the ECJ held that such a requirement is consistent with the Services Directive, indicating that it would require specialist knowledge on the part of national courts to determine whether the requirements laid down are compatible with the principle of proportionality in the Services Directive. As the Court imposed the conditions of unambiguity, objectivity, publicity, transparency and accessibility it did not grant the national courts unlimited discretion. The Court also emphasized in the judgment that it is important that landlords wishing to rent out their apartments to tourists should be able to acquaint themselves with the authorisation conditions related to the access or exercise of this activity ${ }^{36}$ prior to engaging in it (paragraphs 104 to 107 of the judgment).

\subsection{Addressing the housing shortage as a public interest}

Certain judgments of the $\mathrm{EC}^{37}$ point out that the rationale set out in Article 9 (1) of the Directive 2006/123/EC, relating to the authorisation scheme, should be justified by an overriding reason relating to public interest and the solution adopted must comply with the principle of proportionality. In regard to the contents of the judgment C-724/18, it can be stated that the Court noted that the French legislation in force is aimed at establishing a mechanism to combat the shortage of housing for long-term rental in response to the deterioration of the access to housing, (also caused by rising rental prices), which constitutes an overriding reason relating to the public interest. On the other hand, the national legislation in question is considered to be proportionate in so far as it does not go beyond what is strictly necessary to achieve the pursued objective.

Under Article 10 (2) of the 2006/123/EC Directive the criteria for granting authorisations must be justified by the overriding reasons relating to the public

36 Article 72 Constitution de la République Française (Constitution of the French Republic), available at: http://biblioteka.sejm.gov.pl/wp-content/uploads/2015/10/ Francja_pol_010711.pdf

37 E.g. Judgment of the CJEU, Case C-293/14. 
interest, proportionate to that public interest objective, clear and unambiguous. They must also be objective, made public in advance, transparent and accessible. The responsibility to establish whether the authorisation scheme implemented in a given state takes into account the shortage of housing for long-term rental will lie with national courts. In light of the above, it is reasonable to assume that preventing the shortage housing for long-term rental constitutes important public interest that justifies state intervention.

\section{THE COVID-19 PANDEMIC AND THE NEED FOR CHANGES IN THE RENTAL MARKET}

According to the Eurostat ${ }^{38}$ data from 2021, average rental prices in the European Union have seen a steady increase over the last ten years. On average, sales prices of houses and flats have increased twice as much as the rent. COVID-19 pandemic is certain to affect the prices. The demand for short-term rentals has already gone down dramatically as a result of a temporary ban on rental activities and decreased numbers of tourists. At the moment it is difficult to forecast if and when the estate market, including short-term rentals, will return to its pre-pandemic condition. Certainly, the pandemic and the changes may provide a good opportunity to review the regulations on short-term rentals in the states where they already exist and to introduce them in the states where they are still not implemented. The judgment C-724/18 of the Court thus opens the way for the Member States of the European Union to reasonably regulate the market for short-term rentals of residential premises.

Short-term rental, which is in essence akin to hotel operations, may be a burden for the tenants occupying the building with such a unit used for this purpose. Frequent turnover of tenants leads to excessive noise which is generally a problem associated with the presence of tourists. What is more, residential units are not well-adapted to perform hotel functions also due to fire protection issues. Frequent turnover of tourists also results in accelerated deterioration of the building's common areas and subsequent raise in maintenance payments. A greater supply of short-term rentals may also lead to the increase in rent, affecting city residents and students. Authorisation schemes, or at least an obligation to register units designated for short-term rental would be a solution to this problem, as it would allow the relevant authorities to assess if the concentration of short-term rentals in a given area is not excessive.

38 Available at: https://ec.europa.eu/eurostat/en/web/products-eurostat-news/-/ddn20210114-1. 
Thanks to the ECJ judgment, the Member States may implement an authorisation scheme for operators of short-term rentals and thus limit the number of service providers, but only on condition that such a scheme is non-discriminatory with respect to the service provider in question and justified by overriding reasons relating to the public interest. The introduction of restrictions must be justified and the implemented measures must be proportionate to the protected interest. The purpose of such restrictions should be to pursue a housing policy best suited for the needs of the given state. ${ }^{39}$ Regarding the issues related to limitation of freedom of economic activity, it is worth remembering that, similarly to the right to property, these rights are not of an absolute nature and in certain cases may be subject to certain limitations.

\section{CONCLUSION}

To sum up, the judgment in question is of great importance from the perspective of the further development of the regulations pertaining to short-term rental. It will result in legislative initiatives in this area. It is a fact that metropolitan cities such as Paris have been coping with a scarcity of affordable residential property for many years and even decades. The massive amount of properties that were let through e.g. AirBnB or Booking to tourists over the past years has only driven the housing prices higher and higher. In connection with the wording of the ECJ judgment, on January 6, 2021, the European Parliament asked the European Commission three important questions (out of all six) ${ }^{40}$ related to the future regulation of short-term rental. ${ }^{41}$ It was noted that the Court of Justice observed that combating shortages in the rental housing markets constitutes an overriding public interest reason, given its implications on citizens' basic needs, urban environments and social policy objectives.

The first question is whether, following the judgment of Court of Justice of 22 September 2020 (C-724/18), "is the Commission planning to issue guidance for authorities on how to regulate short-term letting in a proportionate and effective

39 Bończak-Kucharczyk, E., Ochrona praw lokatorów i najem lokali mieszkalnych. Komentarz. Nowe rodzaje najmu. Gospodarowanie zasobami samorzqdowymi (Protection of the rights of tenants and rental of dwellings. Commentary. New types of lease. Management of local government resources), Wolters Kluwer Polska, 2019, pp. 21 et seq.

40 By its third, fourth, fifth and sixth questions, the referring court asks, in essence, about single issue. See: point 54 of the Judgment.

41 Parliamentary questions, 6 January 2021, Question for written answer E-000050/2021 to the Commission, Rule 138, available at: https://www.europarl. europa.eu/doceo/document/E-9-2021-000050_EN.html. 
way within the framework of EU rules, and in particular on the interpretation of the Services Directive". The next question is whether the regulations of the "Digital Services Act proposal oblige short-term holiday rental platforms to request proof of compliance with local authorisation schemes if these exist". This question also covered the issue of the mandatory exchange of such data. A third key question for the real estate market is whether the Commission is "considering the introduction of sector-specific rules on short-term letting, that would, for example, introduce an EU-level obligation to put in place such interfaces".

The pandemic is sure to affect the real estate market but it may also be a good opportunity to verify the existing regulations or to address the absence thereof, which was also emphasized by the judgment of the Court. I agree with the opinion that preventing shortages of housing for long-term rent represents an overriding reason relating to the public interest and as such justifies restrictions imposed on short-term rentals. Residential property markets differ in every Member State and each has its specific needs. Seeing the large number of municipal authorities following the European Court of Justice, this movement might result on the long run in strenuous lobby work against internet platforms for booking accommodation, measures and penalties against their illegal practices. Additionally, the business model of functioning of online platforms for booking accommodation in EU Member States is being at stake. The ECJ judgment imposes an obligation on national courts to carry out a comprehensive assessment of the situation in this area in order to meet new challenges. It provides an opportunity for national legislators to regulate short-term rental in a way that ensures fair competition and protection of customers. The postulated solution is to adopt appropriate legal regulations at the level of national law, which would, above all, ensure effective protection of consumers, and to consider adopting appropriate solutions at the local level, which would enable local authorities to influence the development of short-term rentals.

\section{BIBLIOGRAPHY}

Aloni, E., Pluralism and regulatory response to the sharing economy, in: Davidson, N.; Michele, F.; Infranca, J. (eds.), Cambridge handbook of the law of the sharing economy, Cambridge University Press, Cambridge, 2018, pp. 101-120.

Badura, E., Legal aspects of short-term lease agreements - on a comparative background, Societas et Iurisprudentia, vol. VIII, 2020, pp. 51-61.

Biernat, S., Zasada pierwszeństwa prawa unijnego po Traktacie z Lizbony, Gdańskie Studia Prawnicze, vol. XXV, 2011 , pp. 47-61. 
Bończak-Kucharczyk, E., Ochrona praw lokatorów i najem lokali mieszkalnych. Komentarz. Nowe rodzaje nајтu. Gospodarowanie zasobami samorzqdowymi, Wolters Kluwer Polska (no.) 4, 2019.

Cybula, T., Ustugi turystyczne. Komentarz, Wolters Kluwer Polska, Lex, 2012.

Doliwa, A., Prawo mieszkaniowe. Komentarz, C.H. Beck (no.) 6, 2020.

Edelman, B. G.; Geradin, D., Efficiencies and regulatory shortcuts: How should we regulate companies like Airbnb and Uber?, The Stanford Technology Law Review, vol. 19, no. 2, 2016, pp. 293-328.

Espinosa, T. P., The cost of sharing and the common law: How to address the negative externalities of home-sharing, Chapman Law Review, vol. 19, 2016, pp. 597-627.

Gottlieb, C., Residential Short-Term Rentals: Should Local Governments Regulate the "Industry"?, Planning \& Environmental Law, 2013, pp. 34-61.

Hamari, J.; Sjöklint, M.; Ukkonen, A.; The Sharing Economy: Why People Participate in Collaborative Consumption, Journal of the Association for Information Science and Technology, vol. 67, no. 9, 2016, pp. 2047-2059.

Hatzopoulos, V.; Roma, S., Caring for sharing? The collaborative economy under EU law, Common Market Law Review, vol. 57, no. 1, 2017, pp. 81-127.

Kaźmierczyk, A., Issues of short-term rental in light of EU and member states regulations, PWPM - Review of International, European and Comparative Law, vol. XVII, 2020, pp. 180-198.

McNamara, B., Airbnb: a not - so - safe resting place, Colorado Technology Law Journal, vol. 13, 2015, pp. 149-170.

Miller, S.; Jefferson-Jones, J., Airbnb and the battle between Internet exceptionalism and local control of land use, Probate and Property, vol. 31, 2017, pp. 36-39.

Strzelczyk, R., Prawo nieruchomości, C.H. Beck (no.) 6, 2019.

Szejna, A.; Kosicki, A., Karta Praw Podstawowych Unii Europejskiej i jej znaczenie dla Polski i Europy, Fundacja Praw Podstawowych, Warszawa, 2008.

Varma, A.; Jukic, N.; Pestek, A.; Shultz C. J.; Nestorov S., Airbnb: exciting innovation or passing fad?, Tourism Management Perspectives, vol. 20, 2016, pp. 228-237.

\section{SOURCES}

Directive 2006/123/EC of the European Parliament and of the Council of 12 December 2006 on services in the internal market, OJ L 376, 27.12.2006.

Gesetz zur Verbesserung des Mietrechts und zur Begrenzung des Mietanstiegs sowie zur Regelung von Ingenieur- und Architektenleistungen (Law to 
improve tenancy law and to limit rent increases and regulate engineering and architectural services), Mietrechtsverbesserungsgesetz - MRVerbG of 4.11.1971.

The Law for a Digital Republic, Loi n²016-1321 du 7.10.2016 no 1, www. legifrance.gouv.fr.

Loi n ${ }^{\circ}$ 2018-1021 du 23.11.2018 portant évolution du logement, de l'aménagement et du numérique (Loi ELAN), JORF nr 0272, 24.11.2018, nr 1, (The law on the evolution of housing, land management and digital technology-ELAN), www.legifrance.gouv.fr.

Ley de Arrendamientos Urbanos (LAU) Real Decreto-ley 7/2019, de 1 de marzo, de medidas urgentes en materia de vivienda y alquiler (Urban Leasing Law (LAU) Royal Decree-Law 7/2019, of March 1, on urgent measures regarding housing and rent).

Opinion of Advocate General Bobek of 2 April 2020 in the case C-724/18, Cali Apartments SCI i HX v. Procureur général près la cour d'appel de Paris $i$ Ville de Paris, http://curia.europa.eu/juris/celex.jsf?celex $=62018 \mathrm{CC} 0724 \& \operatorname{langl}=$ pl\&-

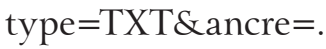

Constitution de la République Française (Constitution of the French Republic), http://biblioteka.sejm.gov.pl/wp-content/uploads/2015/10/Francja_pol_010711.pdf

https://www.conceptosjuridicos.com/lph-articulo-3/ (access 15.12.2020)

https://ec.europa.eu/eurostat/en/web/products-eurostat-news/-/ddn-20210114-1 (access 20.12.2020)

https://www.conceptosjuridicos.com/lph-articulo-3/ (access 15.12.2020)

https://www.boe.es/buscar/doc.php?id=BOE-A-2019-3108 (access 27.11.2020)

https://stat.gov.pl (access 2.01.2021)

http://curia.europa.eu/juris/celex.jsf?celex $=62018 \mathrm{CC} 0724 \& \operatorname{langl}=$ pl\&type $=$ TXT\&ancre $=($ access 20.12.2020)

http://biblioteka.sejm.gov.pl/wp-content/uploads/2015/10/Francja_pol_010711. pdf (access 20.12.2020)

https://www.europarl.europa.eu/doceo/document/E-9-2021-000050_EN.html (access: 17.02.2021) 
Sažetak

\section{Ewelina Badura*}

\section{PRESUDA C-724/18 SUDA EUROPSKE UNIJE OD 22. RUJNA 2020. I NJEZIN UTJECAJ NA TRŽIŠTE NEKRETNINA U EUROPSKOJ UNIJI}

Tijekom 2020. godine dva značajna događaja bitno su utjecala na tržište nekretnina u Europskoj uniji. Prvi je bila pandemija bolesti COVID-19, koja je dovela do velike nesigurnosti, drastičnog pada najamnina i zakupnina te usporavanja rasta na tržištu nekretnina za prodaju. Drugi je bila Presuda C-724/18 Suda Europske unije od 22. rujna 2020., koja je i predmet ovog rada. Sud je u toj Presudi odlučio da sustav prethodnog odobrenja glede kratkoročnog iznajmljivanja namještenih prostora tranzitnim klijentima ne predstavlja povredu slobode pružanja usluga zaštićenu pravom Europske unije. Presuda se, naime, odnosi na dopustivost ograničenja nametnutih od strane lokalnih vlasti poduzetnicima koji se bave kratkoročnim iznajmljivanjem. Ona pritom utvrduje primjenjivost Direktive 2006/123/EZ Europskog parlamenta $i$ Vijeća od 12. prosinca 2006. o uslugama na unutarnjem tržištu na zakonodavstvo država članica koje se odnosi na djelatnosti ponavljanog kratkoročnog iznajmljivanja namještenih stambenih prostora uz naknadu. Sud je u Presudi iznio da je mjera kojom se zahtijeva prethodno odobrenje za obavljanje djelatnosti kratkoročnog iznajmljivanja, koja je uvedena s ciljem rješavanja problema nedostatnog broja stambenih prostora za dugoročni najam, opravdana važnim razlogom u općem interesu te stoga dopuštena. Članak analizira posljedice Presude glede tržišta nekretnina za kratkoročni najam, i u vezi s postojećom pravnom regulacijom i mogućim budućim promjenama.

Ključne riječi: najam, nekretnina, pandemija, Europski sud, turist

* Dr. sc. Ewelina Badura, Ph. D., docentica, Institute of Law, Cracow University of Economics, Rakowicka 27, 31-510 Kraków, Poljska; badurae@uek.krakow.pl;

ORCID ID: orcid.org/0000-0002-5514-6299 